\title{
Irreducible Paraumbilical Hernia with Free Fatty Body and Strangulated Appendix Epiploica in the Sac
}

\author{
Ganesh Shenoy K*, Tulip and Makam Ramesh \\ Department of Minimal Access and Bariatric Surgery, AV Hospital, India
}

Submission: October 21, 2017; Published: November 10, 2017

*Corresponding author: Ganesh Shenoy K, Department of Minimal Access and Bariatric Surgery, AV Hospital, No 9, Patalamma temple street, Basavanaagudi, Bangalore-560004, India, Tel: 9739321584; E-mail: drshenoyganesh@gmail.com

\begin{abstract}
Hernias have a nature to surprise surgeons with their unexpected contents. Twisted and strangulated appendix epiploica of transverse colon and free fatty body as content of irreducible paraumbilical hernia is a rare entity to encounter. We report a 52 year old female with complaints of irreducible paraumbilical swelling associated with pain of one day duration. An ultrasound scan of abdomen showed 2x2 sq.cm defect with features of strangulated omentum in the hernial sac. To our surprise, the content of the sac was a free fatty body with twisted and strangulated appendix epiploica. It was reduced, resected and retrieved laparoscopically. An intraperitoneal composite mesh repair of the paraumbilical hernia was performed at the same sitting. The patient had an uneventful postoperative stay.
\end{abstract}

Keywords: Appendix Epiploica; Paraumbilical hernia; Laparoscopic mesh repair

\section{Introduction}

The common contents in paraumbilical hernia are omentum and small bowel loops. Very rarely there can be colon, appendix or appendix epiploica as content of the sac. Appendix epiploica can occasionally cause acute abdominal pain. The usual presentations are torsion or primary epiploic appendicitis. Torsion of appendices epiploicae of the colon was reported for the first time by Payr in 1902 [1]. Torsion of appendix epiploica inside a paraumbilical hernia is seldom reported in the literature. Irreducible inguinal hernia with appendices epiploica of sigmoid colon in the sac has been described [2]. This case report discusses a rare entity in a patient who presented with a one day history of painful swelling at the umbilical region, but was found to have torsion of epiploic appendix of the transverse colon and a free fatty body as content of the paraumbilical hernial sac which was excised and retrieved laparoscopically. The paraumbilical hernia was repaired using a composite mesh.

\section{Case Report}

A 53 year old female, a known diabetic and hypertensive, presented to the emergency department with a day's history of painful swelling in the umbilical region associated with nausea. There was history of swelling since last 2 years, but was painless and reducible. On physical examination she was tachycardic and febrile. The abdomen was diffusely tender with a tender and irreducible mass over the umbilicus. An ultrasound scan of abdomen showed $2 \times 2$ sq.cm defect with features of strangulated omentum in the hernia sac. She was admitted for emergency laparoscopic hernia repair under general anesthesia (Figures 1 \&2).

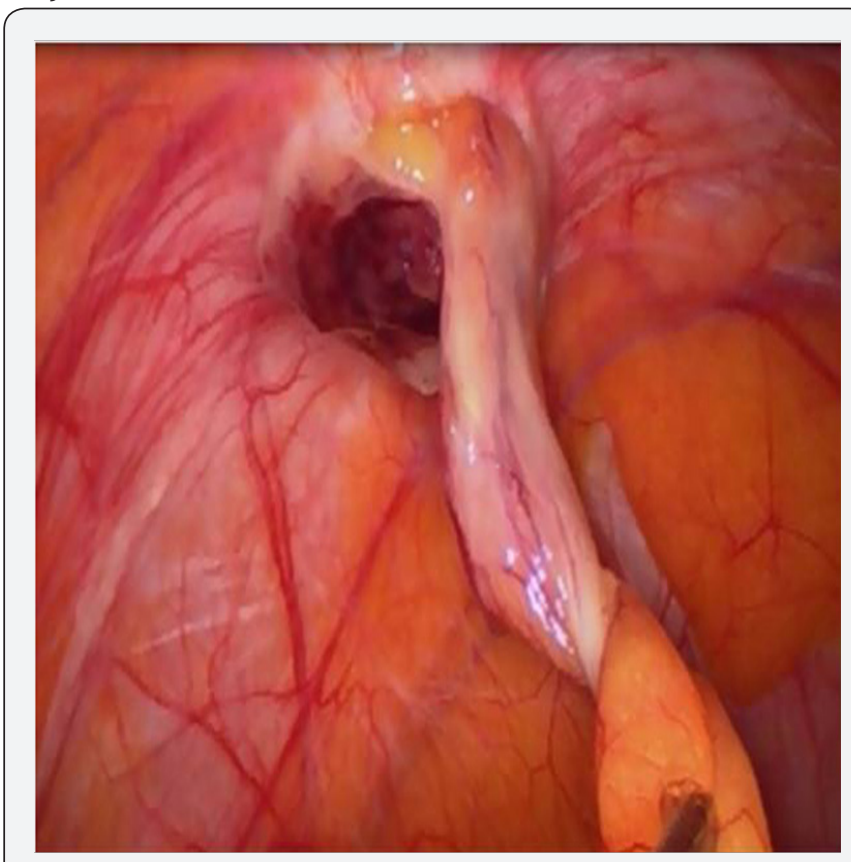

Figure 1. 
On diagnostic laparoscopy we found an oval dark brown mass originating from the anti-mesenteric border of the transverse colon as the content of the sac, suggesting torsion and strangulation of appendix epiploica inside the paraumbilical hernial sac. The free fatty body and twisted appendix epiploica were reduced using atraumatic grasper and bipolar diathermy. The strangulated appendix epiploica was excised completely from the serosa of transverse colon and retrieved in an indigenously prepared endobag along with the free fatty body. The defect was darned using No 1 polypropylene suture. Parietex (Polyester with Collagen layer, Covidien, 15 Hampshire Street, Mansfield, MA 02048, USA) mesh of 10x15 sq.cm size was placed intraperitoneally and fixed with transfascial sutures and tacks.The patient was started on liquids orally after 6 hours and was discharged the next day. At 7 days follow up there was no seroma. At three year follow up the patient does not have recurrence of hernia.

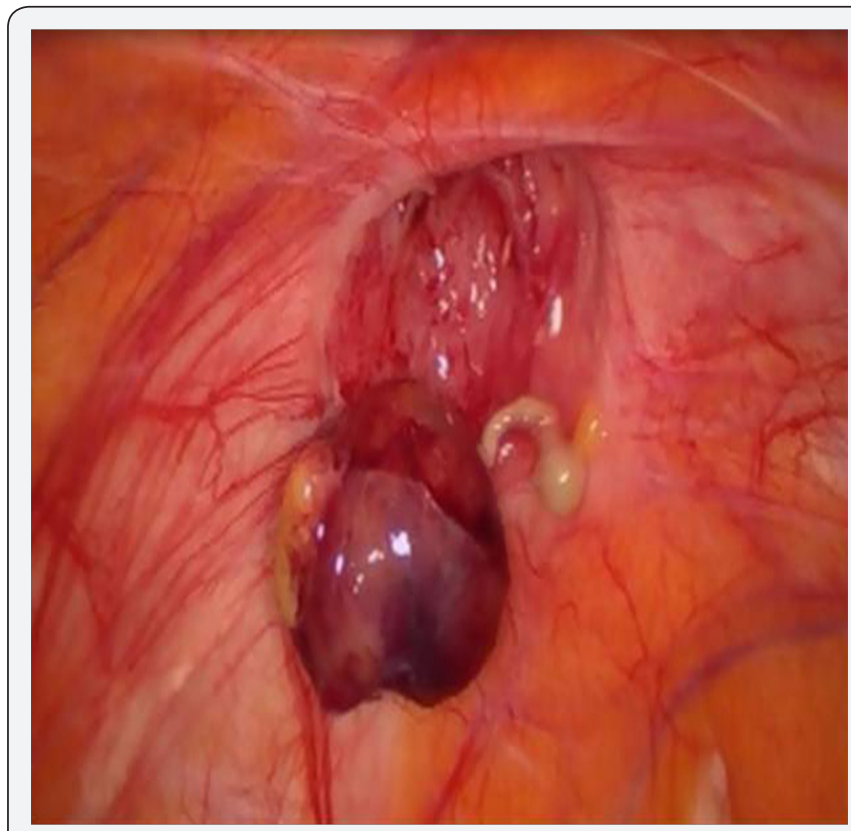

Figure 2 .

\section{Discussion}

The embryology and anatomy of appendices epiploicae have been described by many authors, although Vesalius was the first to describe it in humans in 1543 [3]. These are fatty structures which are attached throughout the length of the colon and are covered by visceral peritoneum. They can measure from 0.5 to
$5 \mathrm{~cm}$ [4]. The exact function of these structures is still not clear, although they may have bacteriostatic properties, may act as a cushion to blood vessels and may perform absorptive action of the large bowel [5]. Epiplioc appendicitis usually presents with abdominal pain, nausea, vomiting, anorexia, and low grade fever. Cases of inflammation of appendices epiploicae in acute abdomen have been reported. The cause of torsion is unknown, but may develop as a consequence of sudden rotation of the body or it may be due to twisting around a long artery or vein or excess fat in the pedicle.

In cases of chronic torsion of the appendix epiploica, the blood supply is shut off; saponification and calcification of fat contents takes place and the pedicle atrophies. Finally, the appendix epiploica detaches from the colon and becomes a peritoneal loose body. Many authors advocate conservative trial with antibiotics and analgesics as it is a self-limiting condition [6]. However, in an irreducible paraumbilical hernia, with ultrasonography showing features of strangulation, emergency laparoscopic repair is the best suited option. To the best of our knowledge, our report is the first in the literature indexed at PubMed wherein the twisted and strangulated appendix epiploica of the transverse colon and free fatty body was the content of the paraumbilical hernial sac. The free fatty body can be considered as a sequel of prior episodes of hernial strangulation or intrahernial torsion of an appendix epiploica.

\section{References}

1. Du Bose JJ, Jenkins DM, Quayle CM, Dress AL, Cotlar AM (2005) Laparoscopic resection of infarcted appendices epiploicae of the colon. Current surgery 62: 362-364.

2. Jain MK, S Sen, B Tantia (2008) Irreducible inguinal hernia with appendices epiploicae in the sac. J Minim Access Surg 4: 85-87.

3. Fieber SS, Forman J (1953) Appendices epiploicae: clinical and pathological considerations; report of three cases and statistical analysis on one hundred five cases. AMA archives of surgery 66: 329338.

4. Molla E, Ripolles T, Martinez MJ, Morote V, Rosello-Sastre E (1998) Primary epiploic appendagitis: US and CT findings. European radiology 8: 435-438.

5. Bastidas JG, Danzy LE, Blackwell L, Bostick PJ, Hayden R (2008) Epiploic appendagitis in a 24-year-old woman. The American journal of emergency medicine 26(838): 831-832.

6. Birjawi GA, Haddad MC, Zantout, HM, Uthman SZ (2000) Primary epiploic appendagitis: a report of two cases. Clinical imaging 24: 207209. 
This work is licensed under Creative Commons Attribution 4.0 Licens DOI: 10.19080/OAJS.2017.06.555698

\section{Your next submission with Juniper Publishers} will reach you the below assets

- Quality Editorial service

- Swift Peer Review

- Reprints availability

- E-prints Service

- Manuscript Podcast for convenient understanding

- Global attainment for your research

- Manuscript accessibility in different formats

( Pdf, E-pub, Full Text, Audio)

- Unceasing customer service

Track the below URL for one-step submission https://juniperpublishers.com/online-submission.php 